\title{
The politics of parliamentary procedure: An analysis of Queen's Speech debates in the House of Commons
}

British Politics (2015), pp.1-22.

\author{
Alexandra Kelso \\ Department of Politics and International Relations, School of Social Sciences, \\ University of Southampton, SO17 1BJ, UK. \\ E-mail: A.Kelso@Soton.ac.uk
}

\begin{abstract}
In the UK Parliament, the State Opening and accompanying Queen's Speech enable governments to set out their legislative plans and delineate their policy choices at the start of each parliamentary session. This article explores the procedural politics of the Queen's Speech debates, and analyses atypical cases to demonstrate the institutional, constitutional and political utility of the process. It examines the 1924 defeated King's Speech; the backbench dissent of the 1946 King's Speech; the volatile Labour Queen's Speeches of the 1970s; and finally the free vote on a government backbench amendment to the 2013 Queen's Speech. In demonstrating the political use of parliamentary procedure, it maps a number of different modes of procedural utility for Queen's Speech debates: to facilitate government; to frame policy debates; to contest policy choices; and to articulate both inter- and intra-party dissent. The article argues that, as a consequence of the Fixed Term Parliaments Act 2011, Queen's Speech debate procedures may become an increasingly important mechanism through which normally marginalised actors pursue their political goals.
\end{abstract}

\section{Keywords}

Westminster parliament; Queen's Speech; parliamentary procedure; parliamentary debates; Fixed Term Parliaments Act 2011 


\section{Introduction}

The UK parliament's Queen's Speech debate does not immediately present itself as an obvious candidate for detailed political analysis. When governments have decent majorities in the House of Commons, the Queen's Speech procedure appears to be largely uninteresting, in part because it is imbued with so much ceremonial ritual, and in part because its outcomes are seemingly certain. However, when the 2010 UK general election resulted in a hung parliament, the politics of parliamentary process grew in salience, because the first test of any minority or coalition government formed would be whether it could win the vote on its Queen's Speech. What had appeared for decades to be a piece of mere ceremonial pomp was revealed instead to be of real political consequence, and a key institutional hurdle which had to be overcome by any coalition of parties that wished to govern. Since 2010, the procedural and parliamentary politics of the Queen's Speech debate have grown in importance, fuelled in part by the consequences of the Fixed Term Parliament Act (FTPA) 2011, and also by growing discussion about whether, given the increasingly complex terrain of multi-party politics at Westminster, there ought to be a formal investiture vote in the Commons to authorise new governments in advance of the Queen's Speech itself.

Rules and procedures matter when seeking to understand institutions. This article explores Queen's Speech debates in the House of Commons in order to analyse the political use of parliamentary procedure. It demonstrates how the seemingly cosmetic occasion of the Queen's Speech in fact underpins crucial and consequential procedural politics which serve simultaneously to legitimise government and also articulate dissent. Analysing the function of Queen's Speech parliamentary debates illuminates the way that actors use the procedure to signal a range of political cues and messages both about the right of governments to govern and about the right of MPs to challenge government. The exploration proceeds through analyses of historical case studies - the defeated 1924 King's Speech; the backbench dissent of the 1946 King's Speech; the volatile Labour Queen's Speeches of the 1970s; and the free vote the government backbench amendment to the 2013 Queen's Speech - whose atypical features usefully highlight the political significance of this debate procedure, and demonstrate its value as an institutional arena for policy contestation and political signalling. The analysis shows how MPs utilise procedural rules for political ends, and, in sketching the politics of the Queen's Speech debate and its position within Westminster's institutional architecture, it seeks to enrich our understanding of the operation of British parliamentary politics, and the crucial way in which procedure facilitates the incorporation of opposition into the 
legitimation of government decision-making.

\section{Procedural politics and institutional rules}

Parliament is a crucial site for multiple political actions. It is the institution through which governments govern, the forum in which MPs hold government to account, the platform on which parties engage in political battle, and the arena in which a range of political and policy messages are transmitted, received and modulated. Consequently, MPs are 'embedded in a complex series of relationships with other individuals', and 'may have to choose among competing institutional loyalties as they act' (Peters 1999, p.26). In contemplating their various institutional commitments, and navigating the influences which shape their behaviour, MPs necessarily interpret the rules which govern their interactions in order to accommodate political objectives. This logic of appropriateness (March and Olsen 1989, 1996) imbues rules with different degrees of salience at different times. Although actors make choices in the context of dominant institutional values, 'even the most thoroughly developed institutions will leave many areas of behaviour open to interpretation by individual members' (Peters 1999, p.29). Although rules are constitutive, and formalise logics of appropriateness, they will also be subject to different interpretations, thus producing different actions for different actors (March and Olsen 1995, pp.21-5; Peters 1999, p.31).

It is within this interpretive space that rules become malleable in the service of actors' objectives, and thus also the space inside which parliamentary capacity can be reimagined. Although institutions are powerful behaviour-shaping entities, their rules are ultimately determined by the actors who abide by them, and actors will utilise the interpretive spaces inside institutions in order to redefine rules where necessary. Processes of parliamentary socialisation (Rush and Giddings 2011) communicate to MPs the dominant institutional values, but such socialisation will only go so far in situations where actors hold multiple and competing goals. In these circumstances, parliamentary procedure can be utilised to profound effect as MPs seek to navigate the parliamentary landscape and the interpretive spaces they discover there.

The Westminster system of parliamentary government exhibits the "nearly complete fusion of the executive and legislative powers' (Bagehot [1867] 2001, p.11), and the delegation of powers from parliament to the cabinet (Saalfeld 2003, p.628) is clearly demonstrated across all parliamentary activity. As a consequence of this delegation, the executive enjoys 
considerable institutional and agenda-setting powers, and can deploy both its partisan and positional advantages to secure legislative goals (Qvortrup 2011), and use parliamentary procedure as a 'political instrument' for governing (Walkland 1968, p.68). But this does not mean that the executive is entirely unconstrained, because 'any delegation of authority entails the risk that the agent may not faithfully pursue the principal's interests', resulting in agency loss (Strøm 2003, p.61). The question of how agency loss is dealt with, and how MPs utilise the institutional rules of the game in response, features prominently in two of the case studies examined below, which illuminate how actors interpret competing institutional commitments when faced with conflicting political goals.

The power of the executive, and the nature of the institutional rules which underpin that power, means that parliament is described as an 'arena' legislature, rather than a transformative one (Polsby 1975). This description can often appear pejorative, but it is in fact highly revealing of the latent power of parliament. The formal means of constraining the executive - for example through general debates and outright rejection of government legislation - are underpinned by informal tactics and off-the-floor activism, which together shape the capacity of parliament to curtail government (Blondel 1973, pp.123-4). Simultaneously, the ability of the executive, through its numerical majority, to revise and manipulate parliamentary procedure renders it 'an important branch in the art of ruling' (Redlich 1908, p.25). The utilization of parliamentary procedure is thus an inherently political activity: the rules of the game enable government to govern while also providing opportunities for opposition. The House of Commons does not itself govern, but provides an arena through which government is maintained, and this is the deceptively simple basis on which the Westminster parliamentary system is based, and through which an opposition, however composed, may draw its procedural power.

Consequently, if we conceive of parliament as a crucial 'theatre of action' (Uhr and Wanna 2000, p.11), then parliamentary activities are a form of 'rehearsed theatre, where adversarial protagonists line up against one another and perform to bolster their own party support ... and shore up their own political credibility' (Rhodes, Wanna and Weller 2009, p.196). To the extent that there is 'drama or even fantasy in the proceedings', such activities are always staged for a dual audience: the electorate outside and the MPs inside (Richards 1987, p.4). If 'state openings, debates, no-confidence motions or resignation speeches all make for grand theatre' (Rai 2010, p.285), where the staging of contestation is framed by the procedural rules 
which govern parliament and enable it to function as a "political site of spectacle and protection' (Rhodes, Wanna and Weller 2009, p.197), then the dual audiences of such theatrical performances are key to the drama's enactment. MPs must know how to adapt to the various parliamentary sites of political drama, and understand 'the endlessly complex procedural rules and different styles of performance for multiple audiences and demands' (Crewe 2015, p.152). The floor of the House of Commons is integral to British political life (Borthwick 1987), and provides a vital stage for open debate and dissent, not just between parties but also inside them. Parliamentary debate takes up the majority of floor time, and is a key deliberative tool (Kelso 2009, p.224), but is often dismissed as irrelevant because government almost always gets its way. But this is to miss the point. Parliament is a talking shop by design (Norton 1981, p.63), and debate compels governments to explain and justify their decisions in a procedural context which enables opposition - both inside and outside the governing party or parties - to exploit unconvincing narratives emanating from the Treasury benches. In securing 'the full discussion and ventilation of all matters' (Amery 1947, p.12), parliamentary procedure is designed to guarantee the opportunity for debate in advance of authorizing government action (Blackburn and Kennon 2003, p.11). Parliamentary procedure structures the arena inside which this public debate and dissension occurs, and thus facilitates the legitimization of government (Judge 1993). Consequently, analysis of actors' strategic use of those parliamentary procedures illuminates the political potential of institutional rules.

\section{The Queen's Speech procedure and parliamentary debate}

Debates, then, are key parliamentary functions, and ones framed by procedural rules, but not all debates are created equally. The ceremony and ritual associated with the Queen's Speech procedure, and its crucial institutional importance, imbues the accompanying debates with a particular intensity. To understand why, we must consider what the procedure itself actually signifies. That parliament is constituted by the House of Commons, the House of Lords, and also the monarch (Dicey 1959, xxxvi; Norton 2013, p.15) is most visibly expressed during the State Opening of Parliament. The authority of kingship was transferred 'to an abstraction called the Crown' in the seventeenth century, but governments still act legally in the sovereign's name (Rose 1983, p.107). Bagehot ([1867] 2001) described the monarchy as the dignified part of the constitution, and although the Queen's constitutional role is now highly restricted, the sovereign is integral to the State Opening of Parliament, without which the business of governing cannot commence. 
State Openings occur annually at the start of each new parliamentary session, and around two to three weeks after a general election when one has been held. The State Opening is highly ceremonial, referencing deep-rooted myths about state functioning which 'condition the public to the powerful symbols used by politicians' (Bennet 1980, p.168), and serve to differentiate elites from non-elites through exclusion from the ceremonial rites performed (Kertzer 1988, pp.17-18), and the political rituals associated with the State Opening undoubtedly imbue the subsequent Queen's Speech debates with additional weight. During the State Opening, the Queen travels to the Palace of Westminster, is adorned with the Imperial State Crown, and moves in procession to the House of Lords, where peers and assorted dignitaries await in their robes and ermines (Rogers and Walters 2006, p.138). MPs are summoned from the House of Commons by Black Rod, and proceed to the Bar of the House of Lords to hear the Queen's Speech read out by the monarch. The Speech provides a broad statement of the government's policy and legislative intent, and is written entirely by the government and approved by the cabinet. It lists the bills that the government intends to introduce, and offers a vague sense of their objectives in relation to the government's agenda (Jennings, Bevan \& John, 2011). Once the Queen has finished reading the Speech, MPs return to the Commons, and pursue various procedural tasks, such as giving a formal first reading to the Outlawries Bill. This is a symbolic activity, which demonstrates the House's assertion of its right to legislate on any matter of its own choosing, whether it was contained in the Queen's Speech or not, thus illustrating the sovereignty of parliament over the executive (House of Commons 2010a). These forms of ritual action, in following 'highly structured, standardized sequences' that are 'endowed with special symbolic meaning' (Kertzer 1988, p.8) add a dramaturgical quality (Goffman 1969) that elevates the procedural architecture surrounding the Queen's Speech.

The Commons debate on the Speech, known formally as the Debate on the Loyal Address, may last up to six days. Formally, the debate is on a motion to present a 'humble address' to the Queen, thanking her for her 'most gracious speech', and makes no explicit reference to anything the speech itself actually contained. The motion tends to read something like this:

We, Your Majesty's most dutiful and loyal subjects, the Commons of the United Kingdom of Great Britain and Northern Ireland, in Parliament assembled, beg leave to offer our humble thanks to Your Majesty for the Gracious Speech which Your Majesty has addressed to both Houses of 


\section{Parliament.}

In practice, however, the debate is focused on the government's policy and legislative intentions as they were outlined in the Speech. After two government backbenchers have moved the motion, the Leader of the Opposition outlines the Opposition's attack on the proposed legislative agenda (Blackburn and Kennon 2003, p.479). The prime minister follows, justifying the government's course of action, after which the debate opens up to contributions from across the House. The first day of debate involves general discussion of the government's proposed legislation, with MPs pressing for details that are typically absent from the Speech, and the following two days are led by the government and focus on particular policy aspects. On the final two days, the opposition parties choose the topics of debate, based on their proposed amendments to the original government motion of 'gracious thanks'. These opposition amendments do not alter the 'gracious thanks' aspect of the motion, but instead add content which 'regrets' that the Speech did not contain various alternative policy and legislative preferences.

As there is both a substantive government motion, as well as the opportunity for MPs to amend that motion, Queen's Speech votes in the Commons were traditionally viewed as the first test of a government following a general election, and its first opportunity to demonstrate that it could command the confidence of the House of Commons (Rogers and Walters 2006, p.140). Consequently, Queen's Speech divisions were effectively viewed as confidence votes, in practice if not in name (Brazier 2008, p.21), even if this position was argued to be constitutionally speculative (House of Commons 2010b, p.8). As we shall see later, the Fixed Term Parliaments Act 2011 has significantly altered the terrain of confidence votes and, thus, the procedural status of the Queen's Speech divisions. Nonetheless, post-election Queen's Speech divisions can be interpreted as crucial parliamentary moments when governments must demonstrate that they possess the authority to govern (Kelso 2015). Although a government with a majority has, by definition, the numerical strength to assume that authority, the Queen's Speech divisions essentially demonstrate that authority through symbolic performance (Kertzer 1988, pp.24-25; Cohen 1974, p.78).

Because of the important symbolism associated with the Queen's Speech procedure, and because the House of Commons can amend the government motion tabled in conjunction with it, the Queen's Speech debate provides a crucial institutional space in which actors can 
interpret important rules in accordance with their goals. Even although the Commons' amending capacity is restricted in relation to the Queen's Speech, actors can nevertheless use their positional discretion to maximise outcomes under those rules (Tsebelis and Rasch 2011, p.7), as the case studies which follow seek to demonstrate. Certainly, these divisions are strongly whipped occasions, through which executives use parliamentary procedure to demonstrate their right to govern, and no government in recent times has failed to win its Queen's Speech vote. The last time a government lost the vote on the Debate on the Address was in 1924, and this especially illuminating example is examined below. Yet focusing only on government success in securing approval for Queen's Speeches can obscure the degree of conflict which may in fact exist, and thus it can also obscure the way in which actors may exploit the procedure and the debate arena in order to pursue goals. Even although Queen's Speech debates are closely managed by the parties, they represent a great deal more that 'mere' performance, precisely because the procedure facilitates conflict resolution in a way that must be accepted as legitimate by the losers (Crewe 2005: p.183, p.200). The case studies which follow illuminate these points and advance our understanding of the way in which MPs utilise parliamentary procedure for politically strategic purposes.

\section{Stanley Baldwin's 'defeated' King's Speech of 1924}

In January 1924, Stanley Baldwin's Conservative government failed to win a vote on its Debate on the Address. Exploration of the events surrounding that lost vote demonstrates how the King's Speech procedure enabled the communication of important political messages and the enactment of crucial constitutional dramas, and although almost a century old, the episode remains highly illuminating. The specific context in which the December 1923 general election was fought structured the parliamentary events which followed. Baldwin became prime minister in May 1923 following the resignation of Bonar Law for health reasons. During the 1922 general election, Bonar Law had run a campaign opposed to tariffs, but on taking office Baldwin expressed his preference for protectionism (Thorpe 2008, p.60), and, in seeking legitimacy to pursue such a policy, called a general election to gather popular authorization for legislative action. These contrasting policy positions thus shaped the outcome of the 1923 election, where the Conservatives lost their majority but remained the largest party in a hung parliament in which it was anything but obvious which party, or parties, ought to have the right to govern. The Conservatives had 258 MPs, Labour 191, and the Liberals 158 , which left open a number of theoretically possible governing outcomes. The importance of trade issues during the campaign made it difficult for Baldwin to remain in 
office as prime minister of a minority government, and Liberal leader Herbert Asquith consequently ruled out supporting Baldwin's continuation in government (Koss 1976, p.264; Jenkins 1978, p.500). That the election had demonstrated the significant flux inside the old two-party system was also a key consideration for Asquith. The rise of Labour from third party to second party status was fundamental to the hung parliament outcome, but despite talk of an anti-socialist alliance, Baldwin believed that such a manoeuvre would lead ultimately to a significant victory for the left (Middlemas and Barnes 1969, p.253), and it was Asquith's 'last decisive act in his political career to persuade the Liberal parliamentary party to stand aside' and permit Labour to come to office as a minority government (Bates 2006, p.135), so that Labour would not be 'soured' by a 'bourgeois alliance' (Jenkins 1978, p.500).

Thus, in consultation with King George V, Baldwin remained in office as prime minister after the election in order to prevent the emergence of support for a Conservative-Liberal alliance that would not only fuel the rise of Labour but would probably also signal the end of Baldwin's political career (Middlemas \& Barnes 1969, p.253; Williamson 1999, p.31). This course of action was endorsed by George V, who advised Baldwin not to resign immediately, but to remain in office to await the verdict of the new parliament (Shepherd and Laybourn 2006, p.41). In terms of political strategy, this course of action enabled the Conservative Party to use the King's Speech occasion to signal to the electorate that it was the Liberals who were putting Labour into power (Bogdanor 2011, p.14), but constitutionally it also ensured that if Labour was to take office as a minority government, it would only do so once it had ascertained from the other parties that it could command confidence and would not be immediately thwarted as a minority administration.

It is at this point where parliamentary procedure facilitated the theatre of action through which these constitutional issues could be resolved. On 15 January 1924, the King's Speech was delivered to parliament by George $\mathrm{V}$, a speech prepared by Baldwin and his still incumbent government. The government moved the motion for the Debate on the Address in the House of Commons, as was standard practice, and the Labour leader, Ramsay MacDonald, immediately moved an amendment to the motion which read, 'But it is our duty respectfully to submit to Your Majesty that Your Majesty's present advisers have not the confidence of this House' (HC Debs., 15 January 1924, vol.169, col.98). Following several days of debate, the House divided and accepted the amended motion 328-256, with the Liberals supporting Labour and thus delivering a verdict of no-confidence in the 
Conservative government. Baldwin resigned, and the King appointed Ramsay MacDonald as prime minister of the first ever Labour government. The resignation of Baldwin and the appointment of MacDonald happened fully six weeks after the general election, the most protracted succession of the twentieth century (Brazier 1994, p.25).

Despite its age, there are a number of important insights from this example of prime ministerial succession and the role of the King's Speech. First, Baldwin remained in office for several weeks after the December 1923 election, and only resigned when he lost the noconfidence amendment attached to the King's Speech motion. That he would not command confidence was apparent quite soon after the election. However, the delay served both constitutional and political functions. Politically, the pause helped Baldwin instrumentally by preventing the emergence of an anti-socialist alliance at his own expense. Constitutionally, the delay enabled the Labour leadership to prepare for the meeting of parliament and to ascertain the willingness of the Liberals to support the no-confidence amendment. In other words, Baldwin presented a King's Speech, not because he realistically expected to muster support for it, but because he believed a minority Labour government would not last long, and that the Liberals would be punished by the electorate for putting them into office. Such strategic manoeuvring applied also to Asquith, who supported the no-confidence amendment because he believed it would enable the Liberals to return to office once the minority Labour government inevitably fell (Koss 1976, p.265). Asquith in fact remarked to a contemporary that he hoped Ramsay MacDonald would enjoy his 'hour of brief rule ... for once out he will never be heard of again' (Bates 2006, p.136). Things did not quite work out that way, and the October 1924 election was entirely disastrous for the Liberals. Nevertheless, at the time there was much to be gained for both the Conservatives and the Liberals, potentially at least, in facilitating the King's Speech vote to play out as it did.

The episode was not some embarrassing political miscalculation, then, but rather a carefully choreographed constitutional dance played out on the parliamentary stage, through which key actors utilised the procedural rules of the King's Speech debate in order to maximise their political positions. Had events not happened in the way that they did, there were alternative scenarios, but not particularly appealing or realistic ones. Baldwin could have resigned his party's leadership to enable another Conservative to become prime minister, but this was always an unlikely option for an ambitious man who had only taken charge of his party a few months before. He could have immediately resigned as prime minister and recommended that 
the King appoint MacDonald in his place, but Labour were so far behind the Conservatives in terms of seat share that the logic of this move would always have been questionable in the absence of some demonstration that MacDonald could in fact command the confidence of the House, which is what the King's Speech division served to demonstrate. This is a fundamental point. The vote served to illustrate who had the authority to govern, and its performance was crucial in imbuing the incoming Labour government with legitimacy. The King's Speech division, and the debate which accompanied it, served to transfer power legitimately from one set of actors to another, and to dampen opposition to that transfer by demonstrating that it was entirely within the rules of the institutional game.

Constitutionally, therefore, the delay between the election and the King's Speech gave the incoming Labour government its best shot at governing with stability, because an alternative government led by Baldwin was demonstrably shown to lack the ability to command confidence. Asquith pointed to another potential outcome at the time, when he remarked that Baldwin 'could easily have snapped his fingers at the no confidence amendment ... and announced that, as leader of much the largest section of the House, he had better moral authority than anyone else to carry the King's Government until he was absolutely blocked' (Koss 1976, p.264). That Baldwin did not assert his party's right to govern in this way points to the sophistication of his political calculation that going into opposition was the best option for both him and his party, and that the smartest move was to let the Liberals suffer by propping up a Labour minority government that Baldwin felt sure was doomed to fall.

The theatre of the 1924 King's Speech, and the procedures surrounding its introduction, debate and amendment, thus served multiple political goals. First, it facilitated the successful appointment of a prime minister of a minority government under complex electoral circumstances where the application of the rules was open to interpretation. Second, it enabled the leaders of the other two parties to use the procedural rules in a way that they each hoped would ultimately be to their own political gain. Through the King's Speech debates, and the confidence amendment procedure ${ }^{1}$, actors used parliamentary procedure to resolve a highly volatile political situation while also attempting to advance their own strategic interests. Finally, in this example, procedural politics was essential for the absorption of new political actors into the governing system, and in thus preserving the stability of parliamentary democracy. 


\section{Backbench Discontent and the 1946 King's Speech}

The example of the 1924 King's Speech maps the role of parliamentary procedure in resolving a volatile electoral outcome. In contrast, the 1946 King's Speech is an example of a 'non-election' Debate on the Address used for quite different purposes, through which government backbench MPs expressed mounting dissatisfaction with their party's policy choices. Labour won the 1945 general election with a majority of 145, and is remembered now for using its landslide victory to introduce the central legislative pillars of the NHS, pursue welfare reform, and nationalise key industries. Yet, the first Labour majority government also experienced considerable disagreement amongst its parliamentary ranks over foreign and defence policy, and backbench Labour MPs utilised parliamentary procedure for the express purpose of more directly influencing the content of government policy. In particular, they used the King's Speech debate and vote in order to signal key political messages to the party leadership under conditions in which they faced competing interpretations of their roles as party loyalists and policy advocates.

In December 1945, after just a few months in office, 23 Labour MPs, including two parliamentary private secretaries, voted against approving the United States loan to Britain, while 44 abstained. This rebellion primed backbench behaviour on subsequent foreign and defence policy issues, which found expression during the following King's Speech. In November 1946, Labour backbencher Richard Crossman moved an amendment to his own government's King's Speech, which demanded that the government 'review and recast its conduct of international affairs' in order to 'provide a democratic and constructive socialist alternative to an otherwise inevitable conflict between American capitalism and Soviet communism in which all hope of world government would be destroyed' (HC Debs, 18 November 1946, vol.430, col.526). The amendment was signed by 56 Labour MPs, including five parliamentary private secretaries (Morgan 1984, p.63), and came just a few weeks after the TUC conference debated a resolution which strongly condemned aspects of the government's foreign policy, and which was only defeated thanks to the role of the unions (Harris 1982, p.301). Crossman justified his amendment on the grounds that the Labour government had significantly departed from the foreign policy undertakings it had made prior to the election, and had become much too close to the United States (col.527). Crucially, however, Crossman made clear that in tabling the amendment he did not seek a vote on it (cols.525, 538), but was instead using it to force the government to answer questions about the nature of the UK relationship with the US (col.534), and to make the case for 'an 
independent British policy' that would remove Britain from the compulsion to join 'any ideological bloc' and thus 'prevent the third world war' (col. 538).

The King's Speech occasion was, therefore, an opportunity for a high profile debate about a serious foreign policy issue which many Labour MPs felt was being inappropriately dealt with by their frontbench colleagues. The debate enabled the amplification of policy dissent, and, crucially, was never about seriously destabilising the government through the blunt tool of the division lobbies. Despite originally planning to force a division, Crossman and the rebels responded to pressure from the prime minister, Clement Attlee, and their fellow MPs at a Parliamentary Labour Party (PLP) meeting and agreed only to table and debate the amendment. However, two independent Labour MPs pressed for a division, and 70 Labour MPs consequently abstained from the vote (Butt 1969, p.190). Conservative MPs voted with the government, to defeat the amendment 353-0 (as the two Independent Labour MPs acted as tellers), and the success of the government in this instance was never in any doubt. Yet the central aim in tabling the amendment and using the King's Speech forum to force debate about UK foreign policy was crucial in demarcating backbench disagreement about the trajectories of government decision-making, and was 'the beginning of a process which culminated the following year in the formation of a consistently critical group on the left mainly identifiable by its anti-Americanism', the so called 'Keep Left' group (Harris 1982, p.303).

Nor did the story end there for the 1946 King's Speech. The nature of the UK's relationship with the US was problematic for some Labour MPs, but so too was the policy of conscription, which was perceived by many on the left to be fundamentally immoral (Butt 1969, p.191). When Attlee met with the PLP in November 1946 and informed them that he wanted to introduce a conscription retention bill, MPs used the opportunity of the King's Speech debate to register their strong opposition which they felt had not been sufficiently acknowledged inside the PLP (Butt 1969, p.193). Thus, as soon as the Crossman amendment been dealt with, another Labour amendment was moved, regretting 'that it is the intention of Your Majesty's Government to embark upon a peace-time policy of military conscription' (col.594). A list of justifications were provided alongside the moral ones, such as the futility of a conscript army in the era of the atomic bomb, the likelihood that conscription would prompt a rush towards military preparedness, and the notion that conscription undermined democracy. Those supporting the amendment used it strategically to encourage the 
government to defer the bill until various international talks had been concluded (col. 599), and the mover of the amendment, Victor Yates MP, declared that 'my constituents never sent me to this House to support a policy of military conscription or military slavery' (col.600). During the amendment debate, the government's position was defended not by the Defence Secretary, who was ill, but by the Chancellor, who endured repeated interruptions during his speech from Labour MPs intent on testing the boundaries of the policy's rationale. When the division was called, 45 Labour MPs voted for the amendment, and around 132 abstained, and for the second time that day, the government found itself in the same division lobbies as the Conservative opposition.

That difficult Commons debate on the King's Speech on 18 November 1946 was just one of many instances of dissent on the Labour backbenches over the direction of post-war foreign and defence policy, and the specific issue of conscription roused further unrest when the promised legislation was introduced as the National Service Bill in 1947 (Butt 1969, p.192). The crucial point, though, is that the King's Speech debate facilitated the expression of opposition from within the governing party after internal parliamentary party processes failed to defuse the policy conflict. The Labour MPs who opposed conscription did not want to defeat their own government in a King's Speech vote, but they did want to demonstrate to government frontbenchers that there were serious divisions inside the party on key policy questions, and that the cost of the inattentiveness to those divisions was walking through the division lobbies with the Conservative Party. The King's Speech conscription amendment episode undoubtedly laid the foundations for the concessions which Labour backbenchers later obtained on the National Service Bill, even if it failed to derail the bill itself, which in fact enjoyed broader public support outside of parliament, and was never in any serious danger given Attlee's authority inside the party (Butt 1969, p.193; Morgan 1984, p.65). Fundamentally, however, the procedural prominence of the King's Speech debate elevated the salience of these policy matters where agency loss was evident and the delegation of authority to the party leadership and parliamentary frontbench was perceived to be detrimental to policy decision making (Strøm 2003). The significance of the King's Speech votes raised the political stakes and amplified the policy signals sent by backbenchers, and the procedure thus served as a key strategic tool for parliamentary actors who, despite being members of the governing party, nevertheless found themselves marginalised from government decision making processes. 


\section{Labour's Volatile Queen's Speeches 1974-79}

Following the political manoeuvring around the 1946 King's Speech, almost thirty years passed before the procedural importance of the Debate on the Address was once more fully demonstrated, and it happened after the February 1974 election, which produced a hung parliament. The incumbent Conservative government, under Edward Heath, lost both vote share and seat share to become the second largest party in the Commons. However, the Conservatives had a larger share of the popular vote than Labour, by some 230,000 votes, and that, combined with the fact that the seat share was balanced on a knife-edge between the two main parties (Labour on 301, Conservative on 297), enabled Heath to remain in office as prime minister for four days following the election, in order to determine whether it was possible to come to an arrangement with the 14 Liberal MPs. Heath only resigned once those overtures proved unfruitful (Butler and Kavanagh 1974, p.255), leading to Wilson's appointment as prime minister.

The significance of the Queen's Speech procedure was rediscovered at this point, as acknowledged by Heath in his contribution to the Debate on the Address when he noted that 'minority government is something which no one in the House has hitherto experienced' (HC Debs., 12 March 1974, col.56). Between 1945 and 1970, post-election Queen's Speech debates had never involved an explicit vote on the government's main motion, with defeat of the opposition amendments resulting in the main motion being approved by the Commons without recourse to the division lobbies (Kelso 2015). However, the minority status of Wilson's government required a clearer demonstration of governing authority and Commons confidence. The opposition amendment tabled to the government's Queen's Speech motion was of the standard variety, expressing regret over the absence of income control legislation, and the debate which followed roamed over this matter and the issue of inflation and the economy more generally. Following the debate, the amendment was negatived without a division (HC Debs., 18 March 1974, vol.870, col.806), and the opposition parties largely abstained from voting on the government's main motion, except for seven nationalist MPs who voted against. Defeating the opposition amendment without a vote, and approving the main motion by way of opposition abstention, was crucial in a minority government situation where, by definition, the massed opposition MPs would have defeated the government.

Parliamentary procedure was thus put to work in two key ways in this Queen's Speech, first by facilitating vocal opposition to the proposed legislation, and then by enabling the minority 
Labour government to pass its motion nonetheless. Put thus, the point appears obvious enough, but for MPs who had become accustomed to the uncontroversial nature of the Queen's Speech debate in terms of actual outcomes, the occasion was crucial in demonstrating how minority government would function within the framework of parliamentary procedure. The new prime minister, Harold Wilson, even intimated the need for a clearer understanding of the impact of parliamentary votes on any given issue when he declared during the Queen's Speech debate that his government would 'not be forced to go to the country except in a situation in which every hon. Member in the House was voting knowing the full consequences of his vote' (HC Debs., 12 March 1974, col.70). When pressed, Wilson indicated that the government would resign only if it lost a vote of confidence; otherwise, 'in case of a government defeat ... the government will consider their position and make a definitive statement after due consideration' (cols.70). Although the abstentions rendered the issue moot, the declaration raised the question of what would have happened had the Queen's Speech vote been lost, or an amendment attached, since neither would have involved the procedural vote of confidence of the sort indicated by Wilson. Of course, neither of these were realistic options for the Conservative opposition, who were unlikely to profit electorally from bringing down a government mere days after it had been formed. But Wilson's statement during the Queen's Speech about how he would react to a government defeat potentially animated parliamentary procedure in new and interesting ways.

The Labour government that was returned to office after the October 1974 general election had a majority of just three, and the dynamics surrounding Queen's Speech votes changed accordingly. The House divided on both opposition amendments to the government motion, defeating both, and on the government's main motion the Conservative opposition largely abstained, and only 14 MPs voted against, mostly from the Liberal Party. This was the first post-election Queen's Speech since 1945 where the House divided on both the opposition's amendments and the government's main motion, and this use of parliamentary procedure demonstrated the importance of the Queen's Speech as a mechanism through which rules are used to signal governing authority. By late 1976, however, Labour's small majority had fallen casualty to defections and by-election defeats (Thorpe 2008, p.202), and in March 1977 its Commons position was so precarious that it had to abstain from an adjournment vote on its own public expenditure white paper, which was then defeated 293-0 (Dorey 2011, p.376). The Conservative opposition tabled a no-confidence amendment a few days later, and, in 
order to remain in office, Labour agreed to a formal pact with the Liberal Party, which shared Labour's desire to avoid an early general election (Holmes 1985, p.104). The pact was not a formal coalition, but a supply-and-confidence agreement, through which the Liberals secured some policy goals in exchange for supporting the Labour government during crucial votes, such as the March 1977 no-confidence vote which the government won by 24 votes thanks to Liberal support (Dorey 2011, pp.389-90). This pact also subsequently involved Liberal MPs voting against the Conservative amendment to the Queen's Speech in 1977. That amendment expressed regret at the absence of "proposals for creating the long term business confidence essential to reduce unemployment and create prosperity' (HC Debs., 9 November 1977, vol.938, col.89), and the participation of the Liberals helped the government to defeat the amendment 299-272.

By August 1978, the Lib-Lab pact had been abandoned, and Labour was again governing as a minority, but Liberal support continued to play a role during November's Queen's Speech divisions. The Liberals supported the Labour government in defeating an opposition amendment on policy towards Rhodesia 323-278, not least because the Liberal's poor standing in the polls made them reluctant to play an instrumental role in bringing down the government (Thorpe 2008, p.203). Yet, the Liberals did not support the government on the final opposition amendment on economic policy, and it was only defeated 312-300 thanks to assistance from nationalist MPs and a few party defectors. During the Queen's Speech debate, Thatcher remarked that if it was the prime minister's choice 'to go to the bitter end, so be it' (HC Debs., 1 November 1978, col.34), a jibe at Callaghan's decision not to call an autumn election and his willingness to rely on piece-by-piece coalition-building to ease the government through key parliamentary votes. The final years of the 1974 Labour government were of course unhappy ones, during which it faced six confidence motions, the last of which in March 1979 it lost by one vote, prompting its resignation (Holmes 1985, p.154). Nonetheless, the Queen's Speech procedure during this time enabled normally marginalised actors to secure political goals through their participation in the debates and votes accompanying these high profile occasions, which assumed enhanced institutional importance under minority government conditions. The political and electoral context therefore shaped the strategic use of parliamentary procedure, and enabled actors to use the Queen's Speech process as a crucial arena for both policy bargaining and political signalling. 


\section{The Coalition's Queen's Speeches in 2010 and 2013}

After 1979, Queen's Speeches became relatively uncontroversial occasions as a consequence of the significant majorities enjoyed by incumbent governments. The hung parliament that emerged from the 2010 general election therefore attracted a great deal of attention, particularly in terms of the party negotiations which eventually produced a formal Conservative-Liberal Democrat coalition five days after the close of polls (Kavanagh and Cowley 2010). The emergence of coalition government meant that the Queen's Speech could not simply rely on the vague lists of general policy intent that characterised previous speeches. Rather, it necessarily had to encapsulate the content of the formal coalition agreement to which the two parties had signed up, in order to provide a degree of certainty over which policy packages they would proceed to support legislatively. In this respect, the Queen's Speech assumed a new degree of political saliency. While looser language inevitably remained, and was usefully employed in areas where the parties disagreed about how to proceed, constitutional measures in particular were spelled out in more instrumental terms, in order to satisfy Liberal Democrats that there would be swift introduction of electoral reform referendum legislation, and also to placate Conservatives who were opposed to electoral system change (Bogdanor 2011, p.82).

The divisions on the 2010 Queen's Speech motion were of course won by the coalition government, but there was an important change in proceedings. Since 1983, the Liberal Democrats had been able to move an amendment to the government motion once those of the official opposition party had been dealt with. In 2010, however, the Liberal Democrats were in the government, and therefore once Labour's two amendments were debated and dispatched, the third amendment was moved by the Scottish National Party, which called for a 'full examination of the Trident nuclear missile system and any possible replacement' as part of the Strategic Defence and Security Review (HC Debs., 8 June 2010, col.295). Labour MPs largely abstained from participating, which was not unusual for the third party amendment vote, and it was defeated 27-330. However, the formal involvement of the SNP in this process further underlined the reality of multi-party politics at Westminster, and perhaps even hinted teasingly at events that were to come following the SNP's emergence as Westminster's third party after the 2015 general election.

At the start of the 2013-14 parliamentary session, the Queen's Speech procedure was used in a new way when Conservative backbenchers tabled an amendment to the debate motion 
criticising the speech for not containing legislation for a referendum on the UK's continued membership of the European Union. The amendment reflected concerns on the Conservative benches about the rise of the UK Independence Party (UKIP), which had recently performed well in local elections by campaigning on an anti-EU platform, but also signalled irritation amongst those MPs who felt their leadership was insufficiently attentive to the divergence of party opinion over EU membership. As noted earlier, government MPs had last tabled an amendment to their own Queen's (then King's) Speech in 1946, but the 2013 events represented a new form of procedural instrumentalism because, unlike in 1946, there was the prospect that government ministers would vote for the amendment. A Number 10 spokesperson indicated that even the prime minister might vote in favour, and thus in effect condemn his own government's Queen's Speech, in order to demonstrate his commitment to holding a referendum on EU membership (Syal, 2013). According to the same spokesperson, the prime minister was 'relaxed' about government ministers supporting the amendment. This constituted a significant change in the operation of the Queen's Speech, because government ministers had never before been permitted to openly criticise the speech they themselves had written, and the idea that they might vote for its amendment marked a distinct shift in perceptions about what the Debate on the Address signified both politically and institutionally.

This prompted much excitement amongst political commentators, some of whom concluded that the prime minister would have to resign if the Queen's Speech was amended, because parliamentary guidance indicated that it would be tantamount to the loss of a confidence vote (for example, Eaton 2013). However, the landscape of parliamentary procedure had changed after the coalition government came to power, and the introduction of the Fixed Term Parliaments Act 2011(FTPA) fundamentally changed the meaning of confidence motions, which were thereafter explicitly delineated in statute. The provisions of the FTPA meant that, even if David Cameron and his entire Conservative cabinet voted in favour of the EU referendum amendment, it would not automatically require the resignation of the government. Whereas constitutional scholars had previously queried whether particularly high profile divisions - such as those on the Queen's Speech or the Finance Bill - could be treated as de facto confidence motions, the FTPA removed all doubt from the matter. In stipulating that parliaments would last for five years, and thus removing the ability of the prime minister to call a general election at a time of his or her choosing, the FTPA provided for earlier elections only under certain conditions: first, if at least two-thirds of all MPs 
supported it; or, second, if a motion of no confidence was passed by a simple majority and no alternative government could be confirmed by the Commons within fourteen days by way of an explicit confidence motion (House of Commons 2011). Consequently, as the FTPA delineated the rules of confidence motions in statute, neither a lost Queen's Speech vote, nor the attachment of an amendment to the motion, could automatically be equated with a loss of confidence. To demonstrate a loss of confidence, a formal confidence motion would have to be tabled following a Queen's Speech division defeat. A government which lost a Queen's Speech division would not necessarily lose a confidence motion, and thus the connective tissue between the Queen's Speech and confidence was effectively severed. Of course, in practice, any government which lost the main division on its Queen's Speech would almost certainly be under considerable political pressure to resign, but in strict procedural terms, such a resignation would not be essential.

What this means in terms of parliamentary and constitutional practice remains unclear. On the one hand, there is the potential that Queen's Speech divisions will be reduced in significance, as the government's continuation is not absolutely staked upon winning them. More likely, however, is that the new confidence arrangements have actually enhanced government backbench capacity for action. The 2013 Queen's Speech case lends some support to this view, because the government allowed Conservative backbenchers to have a free vote (unwhipped) on the EU referendum amendment, and this was unprecedented. In 1946, many Labour MPs defied their whip on the issue of conscription, and a great many more abstained altogether, but the position of the whip was clear. The free vote on the Queen's Speech in 2013, by contrast, enabled 130 MPs to vote for the amendment regretting the absence of legislation on an EU referendum. Although the amendment was defeated 277130, due in part to Labour and Liberal Democrat MPs voting against, the shifting terrain of confidence motions as a consequence of FTPA facilitated the expression of dissent not just through debate contributions, as in 1946, but through the division lobbies too, without automatically endangering the continuation of the government. In 1946, Richard Crossman did not want his amendment put to division, and when a division was forced, he and likeminded Labour MPs abstained, as also happened with the conscription amendment, not just because of the implications for the government of defeat, but because of what it meant to vote against the instructions of the party whip. In 2013, a significant number of Conservative MPs used the free vote context to signal discontent in a procedural landscape that had been fundamentally altered by FTPA. The parliamentary procedures underpinning the Queen's 
Speech were thus utilised to very public political effect, and resulted in the government bringing forward the publication of a draft EU Referendum Bill to placate backbench concerns.

In this instance, the government knew that the backbench amendment would not be successful, and the prime minister did not even participate in the debate. What is most interesting about this episode, however, is how the Queen's Speech debate forum was utilised to communicate policy dissent in this high profile way, and under procedural circumstances which had changed considerably. The EU Referendum Bill which was introduced by the government in June 2013 eventually succumbed to intractable coalition disagreements and did not complete its legislative stages (Lusher, 2014), but the Queen's Speech amendment nevertheless served its purpose of signalling to the Treasury benches that there was deep unease amongst Conservative MPs about party policy on Europe. On 10 November 2014, just a few weeks after the collapse of the EU Referendum Bill, Eurosceptic Conservative backbenchers again pressed their case during a debate on EU justice and home affairs powers, which controversially excluded specific approval for the European arrest warrant which the prime minister had previously promised, resulting in an evening of procedural chaos in the Commons and significant Conservative backbench rebellion in the division lobbies (Mason and Sparrow, 2014).

Contextualised thus, the 2013 Queen's Speech amendment moved by Conservative MPs constituted the opening shot of yet another battle waged inside the Conservative party over the issue of Europe. The tabling of the amendment demonstrated the willingness of backbench MPs to take that battle onto the floor of the House of Commons in an extremely high profile manner which primed, if it did not exactly cause, subsequent Commons behaviour over European policy. Although the continuation of the government was clearly not in doubt in relation to the 2013 Queen's Speech amendment, the high profile nature of this debate occasion, and the amendment procedures underpinning it, enabled backbench MPs to very publicly articulate policy dissent in a way which compelled the government to take far speedier action than it may have otherwise done. The amendment procedure served not only to communicate to frontbenchers the view held by a sizeable cohort of backbenchers that EU policy needed to be revisited, at the very least, but also enabled those backbenchers to communicate to various external audiences (the media, constituents, potential UKIP voters, etc.) their own clear stance on the necessary direction of Conservative party policy on 
Europe.

\section{Conclusions}

Queen's Speech debates, perhaps above all else, demonstrate how parliament functions as a crucial theatre of action (Urh and Wanna 2000, p.11), through which policy preferences are articulated and justified by governments, and then challenged and probed by Commons MPs, within a framework of highly consequential institutional rules. The expression of dissent is a fundamental purpose of parliamentary deliberation, and debates provide both for that dissensus (Palonen, Rosales and Turkka, 2014), and also for its legitimate dispatch in accordance with agreed parliamentary procedures. Exploration of the atypical Queen's Speech debate cases mapped here illustrates the fundamental importance of parliamentary procedure for delineating governmental capacity for policy action, facilitating dissent, and maximising the institutional position of political actors, and the symbolism and rituals associated with the Queen's Speech procedure imbues these debates with particular political salience. In the 1924 example, procedures were used constitutionally in order to resolve an inconclusive election outcome, but were also used politically by the pragmatic Stanley Baldwin in order to thwart his Commons rivals. The 1946 case showed that a large Commons majority does not automatically mean that King's/Queen's Speech debates will be uncontroversial, and further illustrated how backbench MPs, motivated by disagreements with their party leadership, can use parliamentary procedures to signal policy dissent which has not been sufficiently acknowledged through less public bargaining forums. The trials of the Labour government in the 1970s demonstrated the importance of parliamentary procedure in facilitating coalition-building inside the Commons, and the use of the Queen's Speech vote as an opportunity to demonstrate in a highly visible manner whether a government can in fact govern. Finally, the 2013 case illustrated how changes in institutional rules can radically alter the political meaning of parliamentary processes, and consequently open new avenues of policy dissent for backbench actors. Each case affords a different angle of political analysis, which together demonstrate a crucial point, namely that parliamentary procedures matter for political and policy outcomes, and we enrich our understanding of Westminster politics by analysing the institutional opportunities afforded through procedures that might otherwise seem politically redundant in a majoritarian system. In this analysis, debate procedures are crucial for facilitating deliberation about, and resolution of, the dissensus that is inherent in parliamentarism, and in enabling governments to demonstrate their ability to overcome legitimate challenges to their authority. 
The cases examined demonstrate a number of different modes of procedural utility for Queen's Speech debates: to facilitate and authorise government, to frame policy debates, to delineate policy choices, and to signal both inter- and intra-party dissent. The institutional context in which rules operates matters, and how actors use those rules within that context matters even more, as the 2013 Queen's Speech debate demonstrated to quite remarkable effect. The FTPA's decoupling of Queen's Speech divisions from confidence votes enables those debates to occupy new institutional terrain in which backbench MPs may have far greater latitude for policy action than ever before. The evolution of parliamentary rules therefore has important consequences for actors' political capacity for action. In this context, it is worth acknowledging the growing argument in favour of a formal investiture vote at Westminster, in order to explicitly authorise a government in office (Hazell and Paun 2009, 5; HC 528 2011; HC 351, 2014). Should Westminster shift towards formal investiture architecture, this would signal yet another phase in the development of the Queen's Speech debate process. If events in 2013 are anything to go by, such a shift would imbue Queen's Speech debates with an altogether different kind of political salience, facilitating greater capacity for backbench action over policy framing and choices, and thus more clearly positioning parliament as the pre-eminent arena for policy deliberation. To the extent that the continued development of the UK multi-party system denotes a shift away from inevitable and sizeable majority governments, then the Queen's Speech debate process may well become an increasingly valuable institutional site for both inter- and intra-party political and policy contestation, and one that reinvigorates parliament's crucial deliberative role. 


\section{Notes}

${ }^{1}$ The only other example of a confidence amendment being moved during the Debate on the Address followed the 1964 general election which returned a Labour government with a majority of just five seats. Whereas the 1924 amendment explicitly stated that the government 'have not the confidence of this House,' the 1964 amendment cast the confidence statement in policy terms, declaring there to be 'no confidence that Your Majesty's Ministers can implement their proposals without damaging the programmes of modernisation already in train and thus imperilling the future well-being of Your People' (HC Debs., 10 November 1964, col. 969). It was therefore a censure motion, rather than a no confidence motion, and was defeated 294-315 (HC Debs., 10 November 1964, col.969-974). Neither the prime minister, Harold Wilson, nor the Leader of the Opposition, Alec Douglas-Home, took part on the final day of debate when the motion was moved (House of Commons 2010b), which underlined its essentially 'second-order' nature. 


\section{References}

Amery, L.S. (1947) Thoughts on the Constitution. Oxford: Oxford University Press.

Bagehot, W. ([1867] 2001) The English Constitution. Oxford: Oxford University Press.

Bates, S. (2006) Asquith. London: Haus Publishing.

Bennet, L. (1980) Myth, ritual and political control. Journal of Communication 30(4): 166179.

Blackburn, R. and Kennon, A. (2003) Parliament: Functions, Practice and Procedures. London: Sweet \& Maxwell.

Blondel, J. (1973) Comparative Legislatures. Englewood Cliffs, NJ: Prentice-Hall.

Bogdanor, V. (2011) The Coalition and the Constitution. Oxford: Hart Publishing.

Borthwick, R. (1987) The floor of the House. In M. Ryle and P.G. Richards (eds.) The Commons Under Scrutiny. London: Routledge.

Brazier, A. (2008) Parliamentary procedure without a Commons majority. In A. Brazier and S. Kalitowski (eds.) No Overall Control? The Impact of a 'Hung Parliament' on British Politics, London: Hansard Society, pp.27-36.

Brazier, R. (1994) Constitutional Practice. Oxford: Oxford University Press.

Butler, D. and D. Kavanagh (1974) The British General Election of February 1974. London: Palgrave Macmillan.

Butt, R. (1969) The Power of Parliament. London: Constable.

Cohen, A. (1974) Two-Dimensional Man. Berkeley, CA: University of California Press.

Crewe, E. (2005) Lords of Parliament: Manners, Rituals and Politics. Manchester, UK: Manchester University Press.

Crewe, E. (2015) House of Commons: An Anthropology of MPs at Work. London: Bloomsbury.

Dicey, A.V. (1959) An Introduction to the Study of the Law of the Constitution. London: Macmillan.

Dorey, P. (2011) A rather novel constitutional experiment: the formation of the 1977-8 LibLab Pact. Parliamentary History 30(3): 374-394.

Eaton, G. (2013) If the Queen's Speech is amended, the Prime Minister must resign. The Staggers: New Statesman Politics Blog, 10 May 2013, http://www.newstatesman.com/politics/2013/05/if-queen\%E2\%80\%99s-speech-amendedprime-minister-must-resign, accessed 20 February 2015. 
Goffman, E. (1969) The Presentation of Self in Everyday Life. London: Allen Lane.

Harris, K. (1982) Attlee. London: Weidenfeld and Nicolson.

Hazell, R. and A. Paun (eds.) Making Minority Government Work: Hung Parliaments and the Challenges for Westminster and Whitehall. London: Institute for Government.

HC 351 (2014) Role and Powers of the Prime Minister: First Report from the House of Commons Political and Constitutional Reform Committee. London: TSO.

HC 528 (2011) Lessons from the process of Government formation after the 2010 General Election: Fourth Report from the House of Commons Political and Constitutional Reform Committee. London: TSO.

Holmes, M. (1985) The Labour Government 1974-79. London: Macmillan.

House of Commons (2011) Fixed Term Parliaments Act 2011: House of Commons Library, Standard Note SN/PC/6111. London: TSO.

House of Commons, (2010a) The Outlawries Bill: House of Commons Information Office, Factsheet G21, General Series. London: TSO.

House of Commons (2010b) Confidence Motions: House of Commons Library, Standard Note SN/PC/2873. London: TSO.

Jenkins, R. (1978) Asquith. London: Collins.

Jennings, W., Bevan, S. and John, P. (2011) The agenda of British government: the speech from the throne, 1911-2008. Political Studies 59(1): 74-98.

Judge, D. (1993) The Parliamentary State. London: Sage.

Kavanagh, D. and P. Cowley (2010) The British General Election of 2010. Basingstoke: Palgrave.

Kelso, A. (2009) Parliament. In M. Flinders, A. Gamble, C. Hay and M. Kenny (eds.) The Oxford Handbook of British Politics. Oxford: Oxford University Press.

Kelso, A. (2015) A hidden vote of investiture? Parliament and government formation in the United Kingdom. In S. Martin, B.E. Rasch and J.A. Cheibub (eds). Parliaments and Government Formation: Unpacking Investiture Rules. Oxford: Oxford University Press.

Kertzer, D. (1988) Ritual, Politics and Power. New Haven, CT: Yale University Press.

Koss, S. (1976) Asquith. London: Allen Lane.

Lusher, (A. (2014) Plan for EU referendum Bill collapses amid bitter Coalition row. The Independent, 28 October 2014. 
March, J.G. and Olsen, J.P. (1989) Rediscovering Institutions. New York: Free Press.

March, J.G. and Olsen, J.P. (1995) Democratic Governance. New York: Free Press.

March, J.G. and Olsen, J.P. (1996) Institutional perspectives on political institutions. Governance 9(3): 247-64.

Mason, R. and Sparrow, A. (2014) Cameron and May savaged for broken promises over European arrest warrant. The Guardian, 10 November 2014.

Middlemas, K. and Barnes, J. (1969) Baldwin: A Biography. London: Weidenfeld and Nicholson.

Morgan, K.O. (1984) Labour in Power 1945-51. Oxford: Oxford University Press.

Norton, P. (1981) The Commons in Perspective. Oxford: Martin Robertson \& Co.

Norton, P. (2013) Parliament in British Politics. Basingstoke, UK: Palgrave Macmillan.

Palonen, K., Rosales, J.M. and Turkka, T. (eds.) (2014) The Politics of Dissensus. Santander \& Madrid: Cantabria University Press \& McGraw-Hill.

Peters. B.G. (1999) Institutional Theory in Political Science. London: Pinter.

Polsby, N.W. (1975) Legislatures. In F. Greenstein and N.W. Polsby (eds.) Handbook of Political Science, Vol.V. Reading, MA: Addison-Wesley.

Qvortrup, M.H. (2011) United Kingdom: extreme institutional dominance by the executive ... most of the time. In B.E. Rasch and G. Tsebelis (eds.) The Role of Governments in Legislative Agenda Setting. Abingdon: Routledge.

Rai, S.M. (2010) Analysing ceremony and ritual in parliament. Journal of Legislative Studies 16(3): 284-297.

Redlich, J. (1908) The Procedure of the House of Commons, Vol.III. London: Constable \& Co.

Rhodes, R.A.W., Wanna, J. and Weller, P. (2009) Comparing Westminster. Oxford: Oxford University Press.

Richards, P.G. (1987) The role of the Commons. In M. Ryle and P.G. Richards (eds.) The Commons Under Scrutiny. London: Routledge.

Rogers, R. and Walters, R. (2006) How Parliament Works. Harlow: Pearson.

Rose, K. (1983) King George V. Weidenfeld and Nicholson, London.

Rush, M. and Giddings, P. (2011) Parliamentary Socialisation. Basingstoke: Palgrave Macmillan. 
Saalfeld, T. (2003) The United Kingdom: Still a single 'chain of command'? The hollowing out of the Westminster model. In K. Strøm, W.C. Müller and T. Bergman (eds.) Delegation and Accountability in Parliamentary Democracies. Oxford: Oxford University Press.

Shepherd, J. and Laybourn, K. (2006) Britain's First Labour Government. Basingstoke, UK: Palgrave Macmillan.

Strøm, K. (2003) Parliamentary democracy and delegation in K. Strøm, W.C. Müller and T. Bergman (eds.) Delegation and Accountability in Parliamentary Democracies. Oxford: Oxford University Press.

Syal, R. (2013) David Cameron may vote for amendment to his own Queen's speech. The Guardian, 10 May 2013.

Thorpe, A. (2008) A History of the British Labour Party. Basingstoke, UK: Palgrave Macmillan.

Tsebelis, G. and B.E. Rasch (2011) Governments and legislative agenda setting: an introduction. In B.E. Rasch and G. Tsebelis (eds.) The Role of Governments in Legislative Agenda Setting. Abingdon, UK: Routledge.

Uhr, J. and Wanna, J. (2000) The future roles of parliament. In M. Keating, J. Wanna, and P. Weller (eds.) Institutions on the Edge? Capacity for Governance. Sydney, Australia: Allen \& Unwin.

Walkland, S.A. (1968) The Legislative Process in Great Britain. Birkenhead, UK: Allen \& Unwin.

Williamson, P. (1999) Stanley Baldwin: Conservative Leadership and National Values. Cambridge, UK: Cambridge University Press. 
